\title{
Evidence of breeding activity of subadult Turdus thrushes in Argentina
}

\author{
Exequiel Barboza $^{1,2}$, Patricia Capllonch ${ }^{2,3}$, Fernando Diego Ortiz ${ }^{2,4}$ \& Alex E. Jahn ${ }^{5,6}$ \\ 1 Museo de Ciencias Naturales, Fundación Miguel Lillo, San Miguel de Tucumán, Tucumán, Argentina. \\ 2 Centro Nacional de Anillado de Aves (CENAA), Facultad de Ciencias Naturales e Instituto Miguel Lillo, Universidad Nacional de Tucumán, San \\ Miguel de Tucumán, Tucumán, Argentina. \\ 3 Cátedra de Biornitología Argentina, Facultad de Ciencias Naturales e Instituto Miguel Lillo, Universidad Nacional de Tucumán, San Miguel de \\ Tucumán, Tucumán, Argentina. \\ ${ }_{4}$ Centro de Rehabilitación de Aves Rapaces (CeRAR), Reserva Experimental Horco Molle, Facultad de Ciencias Naturales e Instituto Miguel Lillo, \\ Universidad Nacional de Tucumán, San Miguel de Tucumán, Tucumán, Argentina. \\ 5 Environmental Resilience Institute, Indiana University, Bloomington, Indiana, USA. \\ ${ }^{6}$ Corresponding author: alexjahn@iu.edu
}

Received on 04 February 2019. Accepted on 05 August 2019.

\begin{abstract}
Little is known about the age at which many Neotropical bird species first attempt to breed. We evaluated the breeding condition of 515 adult and subadult males and females among four species of Turdus thrushes (T. nigriceps, T. chiguanco, T. amaurochalinus and T. rufiventris) in Tucumán, Argentina during three breeding seasons (2015 to 2018). We registered a total of 126 individuals with brood patches and cloacal protuberances, which accounted for $24.5 \%$ of thrushes in breeding condition that we sampled. Forty thrushes had a brood patch (31.7\% of those in breeding condition), of which 11 were subadults $(8.7 \%)$. Eighty-six thrushes $(68.3 \%)$ had a swollen cloacal protuberance, 18 of which were subadults (14.3\%). Only a few of the subadults in breeding condition built nests, incubated eggs or raised nestlings. Of 130 nests we found, only 3 belonged to a subadult thrush (in all cases, a subadult female with an adult social mate), one of which was successful. Further research on these patterns among various Neotropical bird species could lead to important insights into the life history strategies that characterize different populations, and how these ultimately affect their population dynamics.
\end{abstract}

KEY-WORDS: brood patch, cloacal protuberance, nest, reproduction, Tucumán.

\section{INTRODUCTION}

A substantial body of research has shown that a bird's reproductive performance can vary considerably over its lifetime (reviewed by Newton 1989). Reproductive success in passerines generally improves with age (e.g., Förschler \& Kalko 2006), with older birds initiating nesting activities earlier, having larger broods, and lower rates of nest failure (Robertson \& Rendell 2001). Females that breed in their first year tend to raise fewer offspring per season than older females (Nol \& Smith 1987), although nest success eventually diminishes after peaking in middle-aged females (Robertson \& Rendell 2001). Reproductive success is generally lower when one member of a breeding pair is younger, whereas experienced pairs, consisting of two adults, show higher reproductive performance (Geslin et al. 2004). Thus, the first year in a bird's life appears to be generally characterized by low reproductive success (Förschler \& Kalko 2006).

Evaluating how age influences reproductive success is important for understanding the evolution of life history strategies and the causes of population demographic patterns (Clutton-Brock 1988). According to life history theory, birds should begin breeding when the net benefits are greater than those that promote delaying breeding (Promislow \& Harvey 1990). Breeding at an early age can be beneficial if it reduces the chance of an individual dying before producing offspring or if it maximizes lifetime reproductive success. However, breeding at an early age can be risky if survival of the offspring or of the adults is reduced due to inexperience. Numerous previous studies have shown support for the idea that reproductive success increases with age, due to higher breeding experience of older birds (Nol \& Smith 1987).

Nevertheless, our understanding of the causes of variation in reproductive success with age remains incomplete. It some cases, it is apparent that a positive relationship between reproductive success and age is due to age-related experience in such tasks as foraging (Förschler \& Kalko 2006) and the care of eggs and young (Robertson \& Rendell 2001). Lower reproductive success may also change with age due to senility and lower fertility 
as a bird ages (Partridge 1989). Additionally, as the value of current reproduction increases relative to that of future reproduction (as should be the case with older $v$ s. younger birds), the stress response may be attenuated, with older birds exhibiting higher stress-induced prolactin levels ensuring that reproduction is not suspended compared to younger birds (Angelier et al. 2007).

The genus Turdus is one of the largest avian genera on the planet, comprising 85 species (Gill \& Donsker 2016). Substantial information on how to estimate the age of Turdus thrushes is already available, facilitating research on their age-specific behaviors. Turdus nigriceps and T. rufiventris acquire definitive adult plumage after 14 months and T. amaurochalinus do so in at least 16 months, although they do not necessarily begin to breed at that age (Howell et al. 2003). Molt cycle information is lacking for T. chiguanco; nevertheless, subadults of all the species we studied are in their formative plumage in spring, which is similar to adult plumage except that it is more opaque and heavily worn. They may also exhibit some retained juvenile body feathers and wing coverts (e.g., Ortiz et al. 2017).

Previous research has shown that subadult Turdus thrushes that are one year old may have a well-developed cloacal protuberance, which raises the possibility that these thrushes reproduce before acquiring their adult plumage (Capllonch 2015). Given the gap in information on age-related breeding effort in Neotropical passerines, we evaluated the incidence of breeding activity of subadult Turdus thrushes in northwestern Argentina.

\section{METHODS}

We captured thrushes using mist nets during their breeding season, from September-February 2015, 2016, 2017 , and January-February 2018 at sites located within four major ecosystem types of Tucumán province, Argentina: Montane Chaco Woodland, Temperate Cloud Forest, Subtropical Montane Forest and Lowland Foothill Forest (Cabrera 1976). The sites we worked at are: 1) Ticucho, $26^{\circ} 31^{\prime} \mathrm{S}$; $64^{\circ} 53^{\prime} \mathrm{W}, 600 \mathrm{~m}$ a.s.l.; this site is found in Montane Chaco Woodland, and common trees here are Schinopsis marginata, Acacia caven, Prosopis nigra, Geoffroea decorticans, Ceiba insignis as well as several types of cactus (e.g., Thrichocereus terscheckii, Opuntia sp.); 2) Botanical Garden, Reserva de Horco Molle, 265' 'S; 650.'W, 550 $\mathrm{m}$ a.s.l.; this site is located in Lowland Foothill Forest, with common plants being Heliocarpus popayanensis, Tecoma stans, Juglans australis, Anadenanthera colubrine, Cedrela lilloi, Parapiptadenia excelsa and Allophyllus edulis; 3) El Rulo, Yerba Buena, $1000 \mathrm{~m}$ a.s.l.; this site is in Subtropical Montane Forest and is primarily composed of Cinnamomum porphyrium, Cupania vernalis, Myrsine laetevirens, Myrsine ferruginea, Eugenia mato, Myrcianthes mato, Eugenia pungens, Eugenia seudo-mato, and Prunus tucumanensis; 4) Quebrada del Río Blanquito, town of Tafí del Valle, 26 ${ }^{\circ} 52^{\prime}$ S; 6541 'W, 2400 m elevation; this site is in Temperate Cloud forest and primarily composed of Alnus acuminata with scattered Sambucus peruviana, Rosa rubiginosa; 5) Rancho del Hombre Solo, El Infiernillo, $\mathrm{km} 78$ on Route 307, 2800 m elevation; this site is located $20 \mathrm{~km}$ north of the town of Tafí del Valle $\left(26^{\circ} 49^{\prime} \mathrm{S} ; 65^{\circ} 43^{\prime} \mathrm{W}\right)$ and is primarily composed of grasses (Festuca hieronymeus) and patches of bushes (Iochroma australe, Baccharis sp. and Satureja parvifolia).

\section{Data collection}

We classified a thrush as a juvenile (i.e., hatched during the current season), as a subadult (i.e., hatched during the previous season) or as an adult (i.e., hatched at least two seasons prior to capture) using the amount of skull ossification, the color and texture of the gape (i.e., soft, swollen and yellow in juveniles) and plumage/molt characteristics (e.g., shine, wear, retained juvenile feathers or recently molted; Wolfe et al. 2009, Ortiz et al. 2017).

Turdus can be reliably classified as subadults because they retain the juvenile wing coverts, which exhibit buffy tips, and exhibit swollen gapes for several months during the first year of life (e.g., Ortiz et al. 2017). After breeding and before migrating in fall, they molt body feathers, remiges and rectrices, molting into their basic definitive plumage, which is much brighter and without buffy tips (Capllonch 2015). For example, T. amaurochalinus begins molting immediately after breeding in late summer or in early autumn and continues molt during fall migration (Soria et al. 2008).

We classified a thrush as being in breeding condition by the presence of a swollen cloacal protuberance and a developed brood patch (Ralph et al. 1996) and also determined sex by the presence of a swollen cloacal protuberance (males) or developed brood patch (females; Ralph et al. 1996). For T. nigriceps, we also used sexual dimorphism in plumage as an indicator of sex (Narosky \& Yzurieta 2010).

\section{Nest monitoring}

We conducted nest searches by walking along paths, paying particular attention to forks in branches of trees and shrubs, which are typical locations where thrushes place their cup nests. We also observed the behavior of adult thrushes to find nests, such as escape movements from the nest when we approached. Females will also make a distinct "cluck" call when an observer is near the nest, which helped detect the presence of an active nest. When nests have nestlings, both parents are often 
near the nest and make distinct vocalizations, which aids in finding the nest. We checked nest contents using a ladder or with a video camera attached to a long pole. We classified a nest as successful if it fledged at least one nestling. We classified a nest as failed if there were missing eggs (i.e., which were present in a previous visit to the nest) or when nestlings that were too young to fledge were missing. If a nest failed, it was checked at least once more to determine if it was re-used. If a nestling fledged from a nest, the nest was checked again ten days later to determine if the nest was re-used.

\section{RESULTS}

We caught a total of 515 Turdus thrushes from four species (T. nigriceps, T. chiguanco, T. amaurochalinus and T. rufiventris), 126 of which were in breeding condition, accounting for $24.5 \%$ of all thrushes captured. Forty thrushes had a brood patch $(31.7 \%$ of those in breeding condition), of which 11 were subadults $(8.7 \%)$. Eightysix thrushes $(68.3 \%)$ had a swollen cloacal protuberance, 18 of which were subadults (14.3\%).

We monitored 130 nests, 38 of which belonged to T. amaurochalinus, 12 to T. nigriceps, 38 of T. chiguanco, and 42 to T. rufiventris (Table 1). None of these nests belonged to a subadult male, three belonged to a subadult female, and the rest belonged to adults. Success rates of nests belonging to adults (i.e., excluding the three nests belonging to a subadult female) ranged between 28.6 and $50 \%$ (Table 1). In all three cases in which the nest belonged to a subadult female, their social mate was an adult male. The first belonged to a T. nigriceps subadult female, which was captured next to the nest on 08 November 2016 in El Rulo, San Javier. This nest was successful, fledging three nestlings; the nest was not re-used. The second was a nest of a T. amaurochalinus subadult female, which was captured leaving the nest in Ticucho on 18 November
2017. The eggs were predated and the female did not reuse the nest. The third was located in the basin of the Blanquito River near Tafí del Valle and which belonged to a T. nigriceps subadult female that was captured on 03 Jan 2018 in a mist net placed near the nest. The three nestlings of that nest were killed in an intense storm, likely due to excessive water in the nest, which was placed in a cavity. The nest was not re-used.

\section{DISCUSSION}

We found that subadult Turdus thrushes attempt to breed, although our results suggest that only a small proportion of subadult Turdus thrushes do so. We only found three nests belonging to subadults, such that we cannot yet make definitive conclusions regarding the probability of success between adults and subadults; nevertheless, subadults of both sexes were found in breeding condition. Although we did not find any nests belonging to subadult males, the males we sampled that had a swollen cloacal protuberance may have pursued extra-pair copulations.

Previous research has shown that adults may benefit from holding territories in higher quality habitat with better nest sites and by having more experience with breeding and foraging, allowing them to maintain a proper energy balance, which is key to physiologically preparing for reproduction (Robertson \& Rendell 2001). In contrast, subadult thrushes may use their first year to obtain the necessary skills necessary to successfully breed, such as nest building and foraging. Notably, we found several adult nests abandoned before laying eggs, whereas all nests of subadults had eggs. Further research comparing nest outcomes between adults and subadults at different stages of the nesting cycle may shed light on how these and other bird species develop the skills necessary to nest successfully.

Further studies on age-related breeding effort

Table 1. Nest outcomes for four species of Turdus thrushes monitored in Tucumán province, Argentina.

\begin{tabular}{lcccccc}
\hline Adult nests & $\begin{array}{c}\text { Abandoned } \\
\text { before laying }\end{array}$ & $\begin{array}{c}\text { Failed at } \\
\text { egg stage }\end{array}$ & $\begin{array}{c}\text { Failed at } \\
\text { nestling stage }\end{array}$ & Successful & $\begin{array}{c}\text { Total } \\
\text { nests }\end{array}$ & \% Successful \\
\hline T. amaurochalinus & 1 & 14 & 6 & 16 & 37 & 43.2 \\
T. nigriceps & 0 & 5 & 0 & 5 & 10 & 50.0 \\
T. chiguanco & 4 & 13 & 9 & 12 & 38 & 31.6 \\
T. rufiventris & 1 & 24 & 5 & 12 & 42 & 28.6 \\
Total & $\mathbf{6}$ & $\mathbf{5 6}$ & $\mathbf{2 0}$ & $\mathbf{4 5}$ & $\mathbf{1 2 7}$ & \\
\hline Subadult nests & & & & & & \\
T. amaurochalinus & 0 & 1 & 0 & 0 & 1 & 0.0 \\
T. nigriceps & 0 & 0 & 1 & 1 & 2 & 50.0 \\
Total & $\mathbf{0}$ & $\mathbf{1}$ & $\mathbf{1}$ & $\mathbf{1}$ & $\mathbf{3}$ & \\
\hline
\end{tabular}


in Neotropical passerines not only offers a better understanding of the poorly-understood first year of life of Neotropical birds, it can also provide novel insights into the drivers of population dynamics within and across species, since a trade-off may exist between investing in reproduction early in life and fitness later in life (reviewed by Fay et al. 2016). For example, female Willow tits (Parus montanus) that breed every year of their first five years of life have a lower probability of survival later in life than females that skip breeding during at least one of their first five years of life (Orell \& Belda 2002). Such a relationship between fitness and investment in breeding early in life may vary between populations, with the age at which individuals within a population first attempt to breed often being related to the environmental conditions experienced by each population (Fay et al. 2016). Thus, research on the age at which birds first breed contributes to a deeper understanding of avian life-history strategies and population dynamics, and is a subject for which we still have many gaps to fill.

\section{ACKNOWLEDGEMENTS}

We are grateful to three anonymous reviewers, whose comments greatly improved the manuscript. We thank the Universidad Nacional de Tucumán for allowing us access to the Horco Molle and Ticucho properties. We thank the Municipality of Tafí del Valle for allowing access to Quebrada del Blanquito, and we thank Ing. Juan Manuel Paz for letting us access Rancho del Hombre Solo. Finally, we thank field assistants of the Centro Nacional de Anillado de Aves (CENAA) for all of their help.

\section{REFERENCES}

Angelier F., Moe B., Weimerskirch H. \& Chastel O. 2007. Agespecific reproductive success in a long-lived bird: do older parents resist stress better? Journal of Animal Ecology 76: 1181-1191.

Cabrera A.L. 1976. Regiones fitogeográficas argentinas. Enciclopedia Argentina de Agricultura y Jardineria 1: 1-81.

Capllonch P. 2015. Estrategias de mudas en tres especies de zorzales de Argentina. Hornero 30: 63-68.

Clutton-Brock T.H. 1988. Reproductive success: studies of individual variation in contrasting breeding systems. Chicago: University of Chicago Press

Fay R., Barbraud C., Delord K. \& Weimerskirch H. 2016. Variation in the age of first reproduction: different strategies or individual quality? Ecology 97: 1842-1851.

Förschler M.I. \& Kalko E.K.V. 2006. Age-specific reproductive performance in Citril Finches Carduelis [citrinella]. Ardea 94: $275-279$.

Geslin T., Questiau S. \& Eybert M.C. 2004. Age-related improvement of reproductive success in Bluethroats Luscinia svecica. Bird Study 51: $178-184$.

Gill F. \& Donsker D. (eds.). 2016. IOC World Bird List: Thrushes. https://www.worldbirdnames.org/bow/thrushes/ (Access on 22 September 2019).

Howell S.N.G., Corben C., Pyle P. \& Rogers D.I. 2003. The first basic problem: a review of molt and plumage homologies. Condor 105: 635-653.

Narosky T. \& Yzurieta D. 2010. Aves de Argentina y Uruguay: guía de identificación. Buenos Aires: Vazquez Mazzini.

Newton I. 1989. Lifetime reproduction in birds. London: Academic Press.

Nol E. \& Smith J.N.M. 1987. Effects of age and breeding experience on seasonal reproductive success in the Song Sparrow. Journal of Animal Ecology 56: 301-313.

Orell M. \& Belda E.J. 2002. Delayed cost of reproduction and senescence in the Willow Tit Parus montanus. Journal of Animal Ecology 71: 55-64.

Ortiz D., Jahn A.E., Capllonch P., Cereghetti J. \& Barboza E. 2017. Determinación de edad y muda del Zorzal Plomizo (Turdus nigriceps) en Tucumán, Argentina. Cochabamba: Abstracts of the IX Congreso de Ornitología.

Partridge L. 1989. Lifetime reproductive success and life-history evolution, p. 349-362. In: Newton I. (ed.). Lifetime reproduction of birds. London: Academic Press.

Promislow D.E.L. \& Harvey P.H. 1990. Living fast and dying young: a comparative analysis of life-history variation among mammals. Journal of Zoology, London 220: 417-437.

Ralph C.J., Geupel G.R., Pyle P., Martin T.E., DeSante D.F., Milá B. 1996. Manual de métodos de campo para el monitoreo de aves terrestres. Albany: Pacific Southwest Research Station.

Robertson R.J. \& Rendell W.B. 2001. A long-term study of reproductive performance in Tree Swallows: the influence of age and senescence on output. Journal of Animal Ecology 70: 1014-1031.

Soria K., Aveldaño S. \& Capllonch P. 2008. Interpretación de las mudas del plumaje de tres zorzales comunes de la provincia de Tucumán. Xolmis 3: 19-27.

Wolfe J.D., Pyle P. \& Ralph C.J. 2009. Breeding seasons, molt patterns, and gender and age criteria for selected northeastern Costa Rican resident landbirds. Wilson Journal of Ornithology 121: 556-567.

Associate Editor: Gustavo S. Cabanne. 